\title{
Financial development in Jordan: Where do remittances play a role in bank credit?
}

\author{
Hadeel Yaseen ${ }^{\mathrm{a}}$ and Ghassan Omet ${ }^{\mathrm{a}}$
}

\begin{tabular}{l}
${ }^{a}$ The University of Jordan, Jordan \\
\hline C H R O N I C L E \\
\hline Article history: \\
Received: April 1, 2021 \\
Received in revised format: \\
April 262021 \\
Accepted: April 28, 2021 \\
Available online: \\
April 28, 2021 \\
\hline Keywords: \\
Jordan \\
Remittances \\
Bank Credit \\
Imports \\
Stationarity \\
Vector Error Correction Model \\
(VECM)
\end{tabular}

\section{A B S T R A C T}

The Jordanian economy has been a recipient of huge amounts of remittances. Indeed, for more than a decade now, the inflow of this capital has been fluctuating around 10 percent of Gross Domestic Product (GDP). Within this context, the subject matter of remittances has resulted in the development of a myriad of research issues. One of these issues is the impact of remittances on financial development or bank credit to the private sector. This paper looks at the relationship between financial development and remittances in the Jordanian context. Based on the time period 1992-2019, and time series econometric techniques (co-integration and vector auto-regression, among others), this paper examines the impact of remittances on bank credit to the private sector, and on its main sectoral distributions. The estimated results reveal some interesting findings. There is no long-run stable relationship between bank credit to the private sector and remittances. However, there is a stable long-run relationship between credit to individuals (households) and remittances, and between credit to the construction sector and remittances. These conclusions imply that remittances, on average, promote private consumption in general, and residential spending.

C 2021 by the authors: licensee Growing Science, Canad

\section{Introduction}

No one can underestimate the socio-economic importance of banks and stock markets. Indeed, these institutions ease trading, diversifying and hedging risk, allocate scarce capital resources, monitor the performance of managers and apply corporate control measures, promote savings, and facilitate the exchange of goods and services in general (King \& Levine, 1993). The fact that finance is important, the International Monetary Fund (IMF) and the World Bank (WB) keep, on their respective web pages, their own "financial development index" for a large number of countries across the globe. For example, the IMF's index, which covers 183 countries since 1980, ranks countries in terms of three sub-pillars and these are the depth, access, and efficiency of financial institutions and financial markets. As far as the financial institutions' side of the index, the depth sub-pillar uses bank credit to the private sector in percent of GDP. Indeed, in the empirical literature, a number of papers examine the impact of bank credit on economic growth. On average, this literature reflects a positive role of credit (see, for example, McKinnon, 1973; King \& Levine, 1993; Rajan \& Zingales, 1998; Levine et al., 2000; Opoku et al., 2019; Matei, 2020). Given that bank credit can have positive implications to growth, it is expected that the literature examines the determinants of bank credit itself. Within this context, one variable that has been examined in terms of its impact on bank credit is workers' remittances. This literature involves two opposite views on this impact (Aggarwal et al., 2011; Lay, 2020). While some argue that the impact of remittances on bank credit is positive, others argue that the impact is negative. Relative to the above-mentioned observations and arguments, it is interesting to note that the Jordanian economy, for so long, has been the recipient of huge amounts of remittances. For example, for more than a decade now, this inflow of capital has been fluctuating around 10 percent of GDP.

* Corresponding author.

E-mail address: h.yaseen@ju.ju.edu.jo (H. Yaseen)

(C) 2021 by the authors; licensee Growing Science, Canada doi: $10.5267 /$ j.ac. 2021.4 .028 
This paper looks at the relationship between financial development and remittances in the Jordanian context. Based on the time period 1992-2019, and time series econometric techniques, this paper examines the impact of remittances of bank credit to the private sector, retail end of the market (individuals), trade sector, and to the construction sector.

The rest of the paper is organized as follows. In section 2, a brief review of the literature which examines the nexus between remittances and bank credit is provided. Section 3 presents an outline of the data and methodology. In section 4 , the results are presented and commented on. Finally, section 5 summarizes the findings of the paper, and provides some recommendations.

\section{The Nexus Between Remittances and Bank Credit: Literature Review}

Without banks (and stock markets), it would not be practical for economic agents to sign business contracts. Indeed, these institutions address two sources of "market friction". First, an agent who has funds to invest, must meet with an agent who needs funds to invest them. This source of friction makes the signing of such agreements suffer from high "transaction costs". Second, an agent who has funds to invest, must have relevant information about the agent who needs the funds to invest. Again, this source of friction makes the signing of such agreements suffer from high "information costs" (King \& Levine, 1993). These market frictions notwithstanding, an agent who invests his / her funds, must also monitor and evaluate the performance of the user of the funds. After all, the supplier of capital needs to earn a fair return on the invested capital. For the above-mentioned three reasons, businesses, as well as governments, have established formal financial institutions and markets. In addition, and over time, they have created a growing array of financial products and services. As one might expect, the activities of these institutions are regulated by official institutions such as central banks and stock exchange commissions. As mentioned in the introduction, the IMF and the WB measure financial development (financial development index) across the Globe, and they maintain their databases on their web pages. These indices use some relevant data about financial institutions and financial markets. The financial institutions index is the sum of three sub-pillars, and these are depth (bank credit to the private sector in percent of GDP, assets of pension funds to GDP ratio, assets of mutual funds to GDP ratio, and paid insurance premiums to GDP ratio), access (number bank branches and number of ATM's per 100,000 adults), and efficiency (net interest margin, interest rate spread, non-interest income to total income, overhead costs to total assets, return on assets, and return on equity). The financial markets index is the sum of three sub-pillars, and these are depth (market capitalization to GDP ratio, trading volume to GDP ratio, and total debt securities to GDP ratio), access (percent of market capitalization of largest ten firms to total capitalization, and total number of issuers of debt per 100,000 adults), and efficiency (stock market turnover ratio / trading volume to market capitalization). As far as the financial institutions' side of the index, the depth subpillar uses bank credit to the private sector in percent of GDP. Naturally, the inclusion of this measure in the IMF's and the WB's indices is due to the fact that it is a potentially important determinant factor of real economic growth. This is why the literature examines the impact of remittances, among others, on bank credit. This literature has two opposing viewpoints. The negative view of remittances argues that capital inflow (remittances) acts as a substitute for bank credit (Calero et al., 2009, (Brown, 1994; Woodruff \& Zenteno, 2007). Some of the early papers that support this argument include Guiliano and RuizArranz (2009) and Brown et al. (2013). The positive view, on the other hand, argues that remittances enable individuals to have a first and formal contact with banks. On the supply-side, banks might take into consideration remittances in their valuation of the creditworthiness of the senders and recipients of remittances, and hence increase their lending (Gubert, 2002; Yang \& Choi, 2007). On the demand-side, the recipient of remittances, without previous relationships with banks, discover the benefits that they can receive, and as a result of their improved financial literacy, they may start borrowing from banks (Cole et al., 2011; Lusardi \& Mitchell, 2014). As in other similar research issues, the empirical literature that looks at the nexus between remittances and bank credit uses either cross-country data or single-country data. Some of the cross-country include Aggarwal et al. (2011), Coulibaly (2015), Bhattacharya et al. (2018), Fromentin (2018), Azizi (2020), and Kakhkharov and Rohde (2020), and Keho (2020). Similarly, the papers that examine the impact of remittances on bank credit in single countries include Gupta et al. (2009), Chowdhury, (2011), Demirguc-Kunt et al. (2011), Coulibaly (2015), Misati and Kamau (2018), Giuliano and Ruiz-Arranz (2009) and Mehta et al. (2021).

In his recently published paper, for example, Keho (2020) examines the impact of remittances on financial development (bank credit) in 10 West African countries during the period 1980 to 2017. Based on the panel data analysis, the results show that the inflow of remittances to these countries reduce bank credit to the private sector. Azizi (2020), on the other hand, reports opposite findings. Based on his analysis panel data analysis (fixed-effect estimations) of 124 developing economies during the period 1990-2015, Azizi (2020) states that a 10 percent increase in remittances results in 1.7 percent increase in bank credit to the private sector, and in 1.2 percent in the deposits of banks.

As far as the single-country studies are concerned, Misati and Kamau (2018) look at the relationship between remittances and financial development in Kenya. Based on the time period 2006-2016 (quarterly data), and the results of their analysis (autoregressive distributed lag method), it is stated that a relationship (positive) does exist between, not only remittances and bank credit to the private sector, but also between remittances and number and value of mobile transactions, and number of bank accounts as well. In addition, Mehta et al. (2021) arrive at similar conclusions. Based on their analysis of the impact of 
remittances on bank credit to the private sector in Bangladesh (1976-2021), the results indicate the existence of relationships that run from remittances to bank credit in the long-run, as well as in the short-run.

3. The Data and Methodology

To investigate the nexus between remittances and bank credit, we estimate the following four models:

$$
\begin{aligned}
& \ln \left(\text { Total Credit } t_{t}\right)=\lambda+\beta_{1} \ln \left(\text { Remittances }_{t}\right)+\beta_{2} \ln \left(G D P_{t}\right)+\varepsilon_{t} \\
& \ln \left(\text { Credit to Individuals }_{t}\right)=\lambda+\beta_{1} \ln \left(\text { Remittances }_{t}\right)+\beta_{2} \ln \left(G D P_{t}\right)+\varepsilon_{t} \\
& \ln \left(\text { Credit to Trade }_{t}\right)=\lambda+\beta_{1} \ln \left(\text { Remittances }_{t}\right)+\beta_{2} \ln \left(G D P_{t}\right)+\varepsilon_{t} \\
& \ln \left(\text { Credit to Construction }_{t}\right)=\lambda+\beta_{1} \ln \left(\text { Remittances }_{t}\right)+\beta_{2} \ln \left(G D P_{t}\right)+\varepsilon_{t}
\end{aligned}
$$

where, $\varepsilon$ are the error terms, and t refers to the time period (1992 - 2019). All variables are in real values and logarithm forms (ln). As customary, when the data involves time series (i.e. annual), as in our case, one should start the analysis by testing all variables for their stationarity properties. Following this, the optimal lag structure of the models needed to be determined. Based on the chosen lag length, we test for co-integration using the Johansen-Masulius procedures (maximum eigenvalue / $\lambda_{\max }$ and the trace test / $\left.\lambda_{\text {trace }}\right)$, as follows:

$$
\lambda_{\max }=-T \log \left(1-\lambda_{r+1}\right)
$$

where the null is $r=g$ co-integrating vectors with $(g=0,1,2,3, \ldots)$ against the alternative which is $r \leq \mathrm{g}+1$.

$$
\lambda_{\text {trace }}=-T \sum_{i=r+1}^{k} \ln \left(1-\lambda_{i}\right)
$$

where, the null is $r=g$ opposite the general specification $r \leq 1$.

Once the co-integrating tests are performed, and if co-integrated, the next logical step is to estimate our three vector errorcorrection (VECM) models. This test (VECM) examines the three models in terms of their long run and short run relationship between the variables.

$$
\begin{aligned}
& \Delta \text { Total Credit }_{t}=\alpha+\lambda e_{t-1}+\sum_{i=1}^{n} \text { bisRemittances }_{t-i}+\sum_{i=1}^{n} b i \Delta G D P_{t-i}+\varepsilon_{t} \\
& \Delta \text { Credit to Individuals }_{t}=\alpha+\lambda e_{t-1}+\sum_{i=1}^{n} \text { bi } \Delta \text { Remittances } s_{t-i}+\sum_{i=1}^{n} b i \Delta G D P_{t-i}+\varepsilon_{t}
\end{aligned}
$$

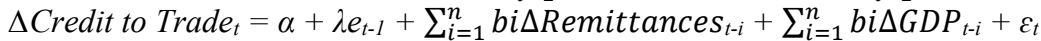

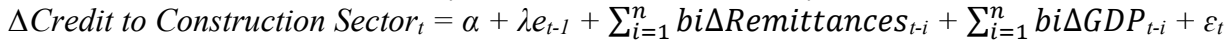

A long-run convergence does exist between the variables if the error correction term $(\lambda)$ is negative and significant. The final step is to examine the models in terms of serial correlation and stability of the residuals. These are examined by the BreuschGodfrey Serial Correlation LM test, and the CUSUM test respectively.

\section{The Empirical Results}

From the outset, it is probably informative to outline a number of observations about bank credit to the private sector, inflow of remittances to the Jordanian economy, and then the estimated results.

A. Based on the published figures by the Central Bank of Jordan (CBJ), one can realize that during the period 1992-2007, bank credit to the private sector to GDP ratio was, on average, rising and hit the 84.0 percent in 2007 . Since then, however, credit to the private sector has fallen to 78.2 percent in 2019 .

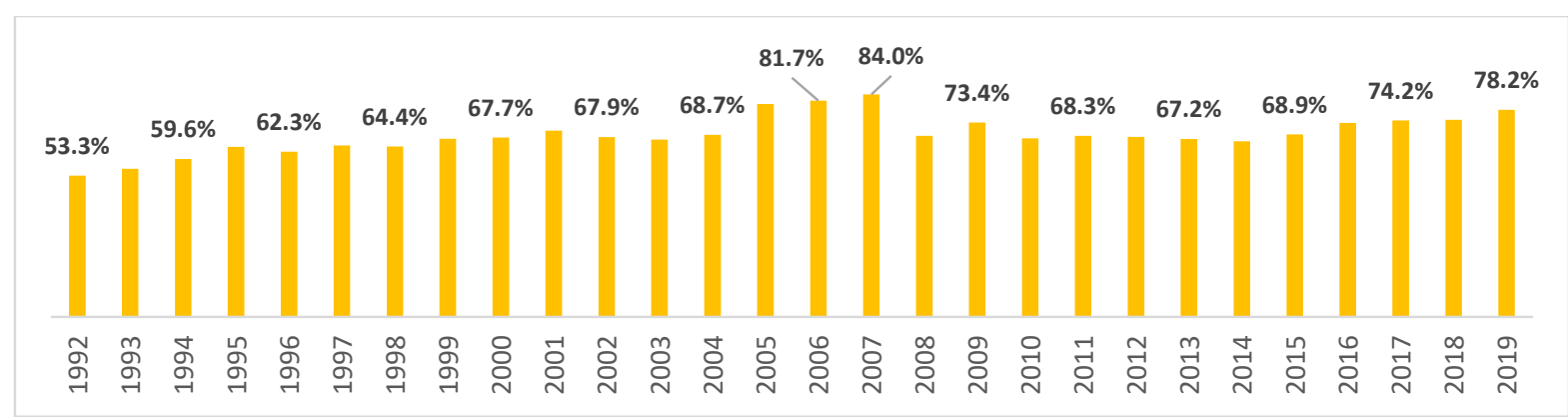

Fig. 1. Bank Credit to Private Sector to GDP Ratio

B. Few sectors dominate the credit market in Jordan. Indeed, individuals, trade, construction, and manufacturing account for 85.1 percent of total bank credit. 


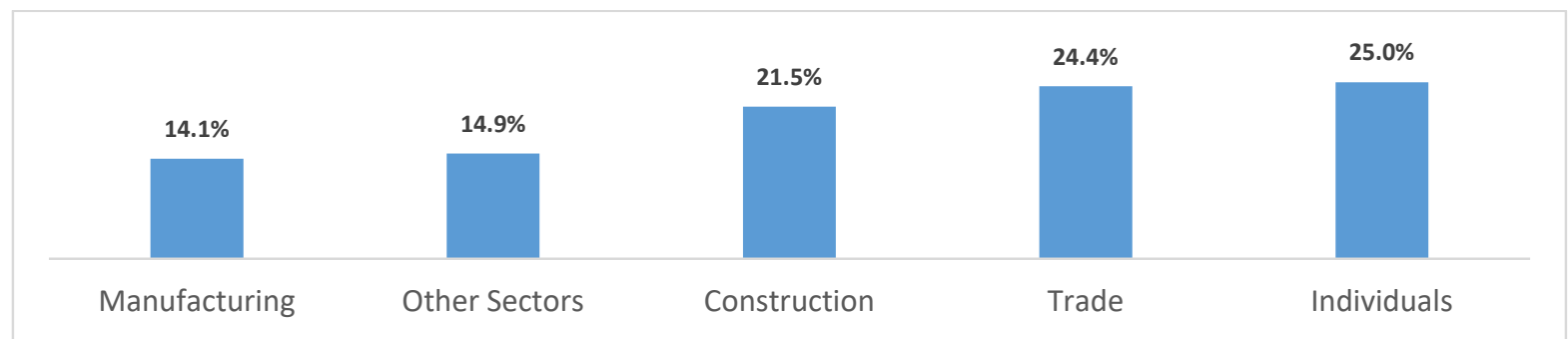

Fig. 2. The Sectoral Distribution of Bank Credit (1992 - 2019)

C. Jordan's mean annual ratio in Jordan (76.0 percent) is much lower than those which prevail in Hong Kong, United States, and in Japan. However, Jordan's ratio is very comparable to other Arab economies (World Bank).

Table 1

Bank Credit to the Private Sector to GDP Ratio (Top \& Bottom 5 Economies \& Arab Economies)

\begin{tabular}{|c|c|c|c|c|c|}
\hline Country & $2017-2019$ & Country & 2017-2019 & Country & 2017-2019 \\
\hline Afghanistan & $3.5 \%$ & Saudi Arabia & $54.0 \%$ & Kuwait & $94.0 \%$ \\
\hline Sierra Leone & $5.6 \%$ & Oman & $73.6 \%$ & Lebanon & $106.3 \%$ \\
\hline Congo & $5.8 \%$ & Jordan & $76.0 \%$ & China & $159.1 \%$ \\
\hline Gambia & $6.2 \%$ & UAE & $78.8 \%$ & Denmark & $160.9 \%$ \\
\hline Guinea & $8.5 \%$ & Morocco & $86.5 \%$ & Japan & $170.9 \%$ \\
\hline Iraq & $8.9 \%$ & Tunisia & $86.6 \%$ & United States & $187.3 \%$ \\
\hline Egypt & $26.0 \%$ & Qatar & $87.2 \%$ & Hong Kong & $226.3 \%$ \\
\hline
\end{tabular}

D. The inflows of remittances to Jordan have been on a declining trend. However, even with the 9.9 percent of GDP, this inflow is still significant. Indeed, the 9.9 percent ratio is higher than for example, Morocco (5.8 percent), and Egypt (8.8 percent). In actual fact, Lebanon boasts the highest proportion (12.5 percent).

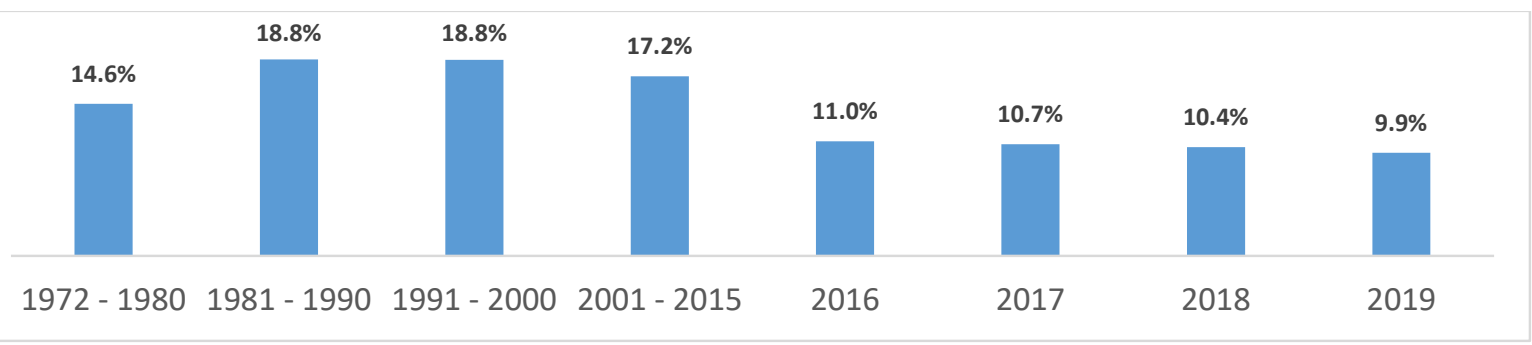

Fig. 3. The Inflow of Remittances to GDP Ratio in Jordan

E. All six variables become stationary once first-differenced (Table 2).

Table 2

Augmented Dickey-Fuller Unit Root Test

\begin{tabular}{|c|c|c|c|c|c|c|}
\hline & None & Constant & Constant \& Trend & None & Constant & Constant \& Trend \\
\hline Total Credit & 8.107 & -1.174 & -2.033 & $-1.7081^{* *}$ & $-3.544^{*}$ & $-3.565^{* *}$ \\
\hline Credit to Individuals & 2.974 & -0.966 & -2.133 & $-3.722^{*}$ & $-8.244^{*}$ & $-7.418^{*}$ \\
\hline Credit to Trade & 1.185 & -0.753 & -2.406 & $-2.214 * *$ & $-3.371^{*}$ & $-3.277^{*}$ \\
\hline Credit to Construction & 2.715 & -0.369 & -1.577 & $-2.288^{*}$ & $-3.761^{*}$ & $-3.647 *$ \\
\hline Remittances & 2.566 & -2.000 & -2.950 & -3.824 & -5.087 & -5.323 \\
\hline Real GDP & 3.671 & -0.4971 & -2.456 & $-3.3879^{* *}$ & $-3.028^{* *}$ & $-4.976^{*}$ \\
\hline
\end{tabular}

F. In Tables 3-6, we report the optimal lag length criteria for the four models. For the endogenous variables, bank credit, remittances, and GDP (Table 3), and bank credit to construction, remittances and GDP (Table 6), the optimal lag length is 2. For the other two models, the lag-length is one period (Tables 4 and 5).

Table 3

VAR Lag Order Criteria

\begin{tabular}{|c|c|c|c|c|c|c|}
\hline \multicolumn{7}{|c|}{ VAR Lag Order Selection Criteria: Endogenous Variables: Total Credit, Remittances, and GDP } \\
\hline Lag & LogL & LR & FPE & AIC & SC & HQ \\
\hline 0 & 38.535 & NA & $1.04 \mathrm{e}-05$ & -2.961 & -2.814 & -2.922 \\
\hline 1 & 131.114 & 154.298 & $9.90 \mathrm{e}-09$ & -9.926 & $-9.337^{*}$ & -9.769 \\
\hline 2 & 143.597 & $17.684^{*}$ & $7.73 \mathrm{e}-09^{*}$ & $-10.216^{*}$ & -9.185 & $-9.942^{*}$ \\
\hline 3 & 149.943 & 7.403 & $1.08 \mathrm{e}-08$ & -9.995 & -8.522 & -9.604 \\
\hline 4 & 154.398 & 4.0836 & $1.97 \mathrm{e}-08$ & -9.616 & -7.702 & -9.108 \\
\hline
\end{tabular}


Table 4

VAR Lag Order Criteria

\begin{tabular}{|c|c|c|c|c|c|c|}
\hline \multicolumn{7}{|c|}{ VAR Lag Order Selection Criteria: Endogenous Variables: Credit to Individuals, Remittances, and GDP } \\
\hline Lag & $\log L$ & LR & FPE & $\mathrm{AIC}$ & $\mathrm{SC}$ & HQ \\
\hline 0 & 5.657 & NA & 0.0001 & -0.204 & -0.05 & -0.162 \\
\hline 1 & 103.573 & $165.70^{*}$ & $1.76 \mathrm{e}-07^{*}$ & $-7.044^{*}$ & $-6.463 *$ & $-6.876^{*}$ \\
\hline 2 & 112.438 & 12.957 & $1.84 \mathrm{e}-07$ & -7.033 & -6.017 & -6.741 \\
\hline
\end{tabular}

Table 5

VAR Lag Order Criteria

\begin{tabular}{|c|c|c|c|c|c|c|}
\hline \multicolumn{7}{|c|}{ VAR Lag Order Selection Criteria: Endogenous Variables: Credit to Trade, Remittances, and GDP } \\
\hline Lag & $\log L$ & LR & FPE & $\mathrm{AIC}$ & $\mathrm{SC}$ & HQ \\
\hline 0 & 31.115 & NA & $2.31 \mathrm{e}-05$ & -2.162 & -2.017 & -2.120 \\
\hline 1 & 125.100 & $159.051 *$ & $3.37 \mathrm{e}-08 *$ & $-8.700^{*}$ & $-8.119 *$ & $-8.532 *$ \\
\hline 2 & 132.136 & 10.283 & $4.05 \mathrm{e}-08$ & -8.548 & -7.532 & -8.256 \\
\hline
\end{tabular}

Table 6

VAR Lag Order Criteria

\begin{tabular}{|c|c|c|c|c|c|c|}
\hline \multicolumn{7}{|c|}{ VAR Lag Order Selection Criteria: Endogenous Variables: Credit to Construction, Remittances, and GDP } \\
\hline Lag & $\operatorname{LogL}$ & LR & FPE & AIC & $\mathrm{SC}$ & HQ \\
\hline 0 & 21.498 & NA & $4.57 \mathrm{e}-05$ & -1.479 & -1.333 & -1.439 \\
\hline 1 & 121.905 & $168.683 *$ & $3.07 \mathrm{e}-08$ & -8.792 & $-8.207 *$ & -8.630 \\
\hline 2 & 132.529 & 15.298 & $2.80 \mathrm{e}-08^{*}$ & $-8.922 *$ & -7.898 & $-8.638^{*}$ \\
\hline 3 & 140.604 & 9.689 & $3.32 \mathrm{e}-08$ & -8.848 & -7.385 & -8.442 \\
\hline
\end{tabular}

G. Based on the estimated lag-lengths, we report the long-term co-integrating relationships for each of the four models. The trace statistic and the maximum eigenvalue statistic's results imply that there is one co-integrating relationship between each of total credit, credit to trade, and credit to construction and remittances and GDP (Table7, 9, and 10). However, the results of the relationship for bank credit to individuals, remittances, and GDP the results indicate the existence of at least 2 cointegrating relationships (Table 8).

Table 7

Johansen Multivariate Co-Integration Test

\begin{tabular}{lcccccccc}
\hline $\begin{array}{l}\text { Hypothesized } \\
\text { No. of CE(s) }\end{array}$ & Eigen Value & $\begin{array}{c}\text { Trace Sta- } \\
\text { tistic }\end{array}$ & $\begin{array}{c}\text { 5 percent } \\
\text { CV }\end{array}$ & P-Value & Eigen Value & $\begin{array}{c}\text { Max-Eigen } \\
\text { Statistic }\end{array}$ & $\begin{array}{c}\text { 5 percent } \\
\text { CV }\end{array}$ & \begin{tabular}{c} 
P-Value \\
\hline
\end{tabular} \\
\hline None ${ }^{*}$ & & & Total Credit, Remittances, and GDP & & \\
\hline At most 1 & 0.737 & 46.067 & 29.797 & 0.0003 & 0.737 & 33.418 & 21.131 \\
At most 2 & 0.359 & 12.648 & 15.494 & 0.1283 & 0.359 & 11.151 & 14.264 & 0.001 \\
\hline
\end{tabular}

Table 8

Johansen Multivariate Co-Integration Test

\begin{tabular}{|c|c|c|c|c|c|c|c|c|}
\hline $\begin{array}{l}\text { Hypothesized } \\
\text { No. of CE(s) }\end{array}$ & Eigen Value & $\begin{array}{l}\text { Trace Sta- } \\
\text { tistic }\end{array}$ & $\begin{array}{c}5 \text { percent } \\
\mathrm{CV}\end{array}$ & P-Value & Eigen Value & $\begin{array}{c}\text { Max-Eigen } \\
\text { Statistic }\end{array}$ & $\begin{array}{c}5 \text { percent } \\
\text { CV }\end{array}$ & P-Value \\
\hline \multicolumn{9}{|c|}{ Credit to Individuals, Remittances, and GDP } \\
\hline None * & 0.738 & 63.07 & 29.797 & 0.000 & 0.738 & 34.886 & 21.131 & 0.001 \\
\hline At most $1 *$ & 0.648 & 28.189 & 15.494 & 0.0004 & 0.648 & 27.156 & 14.264 & 0.001 \\
\hline At most 2 & 0.038 & 1.032 & 3.841 & 0.309 & 0.039 & 1.032 & 3.841 & 0.309 \\
\hline
\end{tabular}

Table 9

Johansen Multivariate Co-Integration Test

\begin{tabular}{lccccccc}
$\begin{array}{l}\text { Hypothesized } \\
\text { No. of CE(s) }\end{array}$ & Eigen Value & $\begin{array}{c}\text { Trace Sta- } \\
\text { tistic }\end{array}$ & $\begin{array}{c}\text { 5 percent } \\
\text { CV }\end{array}$ & $\begin{array}{c}\text { P-Value } \\
\text { Credit to Trade, Remittances, and GDP }\end{array}$ & $\begin{array}{c}\text { Eigen Value } \\
\text { Max-Eigen } \\
\text { Statistic }\end{array}$ & $\begin{array}{c}\text { 5 percent } \\
\text { CV }\end{array}$ & \begin{tabular}{c} 
P-Value \\
\hline None*
\end{tabular} \\
\hline At most 1 & 0.625 & 37.569 & 29.797 & 0.088 & 0.651 & 26.361 \\
At most 2 & 0.237 & 8.170 & 15.494 & 0.447 & 0.454 & 15.155 & 11.264 \\
\hline
\end{tabular}

Table 10

Johansen Multivariate Co-Integration Test

\begin{tabular}{|c|c|c|c|c|c|c|c|c|}
\hline $\begin{array}{l}\text { Hypothesized } \\
\text { No. of CE(s) }\end{array}$ & Eigen Value & $\begin{array}{c}\text { Trace Sta- } \\
\text { tistic }\end{array}$ & $\begin{array}{c}5 \text { percent } \\
\mathrm{CV}\end{array}$ & P-Value & Eigen Value & $\begin{array}{c}\text { Max-Eigen } \\
\text { Statistic }\end{array}$ & $\begin{array}{c}5 \text { percent } \\
\text { CV }\end{array}$ & P-Value \\
\hline \multicolumn{9}{|c|}{ Credit to Construction, Remittances, and GDP } \\
\hline None * & 0.731 & 45.027 & 29.797 & 0.0004 & 0.731 & 32.872 & 21.131 & 0.001 \\
\hline At most 1 & 0.322 & 12.154 & 15.494 & 0.149 & 0.322 & 9.729 & 14.264 & 0.230 \\
\hline At most 2 & 0.092 & 2.425 & 3.841 & 0.119 & 0.0924 & 2.425 & 3.841 & 0.119 \\
\hline
\end{tabular}


H. We now report the estimates of the Vector Error Correction Model (VECM) for all four models.

a. The error correction term for the relationship between total credit and remittances and GDP is positive and not significant. This implies that there is no long run equilibrium relationship between the total bank credit and remittances and GDP. However, for the relationship credit to the construction sector and remittances and GDP, the error term is negative (-0.037) and significant (Table 11). This implies that there is a long run equilibrium relationship. In the long run, the impact of the increase in remittances on credit to the construction sector is equal to +0.854 . The impact of GDP, however, is negative.

Table 11

Results of the Vector Error Correction Models (VECM)

\begin{tabular}{lcll}
\multicolumn{1}{c}{ Variables } & $\Delta \ln ($ Total Credit) & \multicolumn{1}{c}{ Variables } & $\Delta$ In(Credit to Construction) \\
\hline ECT(-1) & +0.047 & ECT(-1) & $-0.037^{*}$ \\
D(Bank Credit)-1 & $+0.438^{*}$ & D(Bank Credit to Construction)-1 & $+0.369^{*}$ \\
D(Bank Credit)-2 & +0.041 & D(Bank Credit to Construction) -2 & +0.097 \\
D(Remittances)-1 & $-0.293^{*}$ & D(Remittances)-1 & -0.175 \\
D(Remittances)-2 & +0.302 & D(Remittances)-2 & +0.108 \\
D(GDP)-1 & -0.032 & D(GDP)-1 & +0.330 \\
D(GDP)-2 & -0.220 & D(GDP)-2 & -0.331 \\
C & $+0.062^{*}$ & $\mathrm{C}$ & $+0.046^{*}$ \\
\hline
\end{tabular}

b. The error correction term for the relationship between credit to individuals and remittances and GDP is negative and significant (-0.362). This implies that there is a long run equilibrium relationship between credit to individuals and remittances and GDP (Table 12). In the long run, the impact of the increase in remittances on credit to individuals is equal to +0.340 . The impact of GDP on credit to individuals is negative (-0.401).

c. The error correction term for the relationship between credit to trade and remittances and GDP is negative (-0.291) and significant. This implies that there is a long run equilibrium relationship between the credit to trade and remittances and GDP (Table 12). In the long run, the impact of the increase in remittances on credit to the trade sector is equal to -0.436 . The impact of GDP, however, is positive (1.019).

Table 12

Results of the Vector Error Correction Models (VECM)

\begin{tabular}{lcll}
\hline \multicolumn{1}{c}{ Variables } & $\Delta \ln ($ Credit to Individuals) & \multicolumn{1}{c}{ Variables } & $\Delta$ In(Credit to Trade) \\
\hline ECT(-1) & $-0.362^{*}$ & ECT(-1) & $-0.291^{*}$ \\
D(Bank Credit)-1 & $+0.446^{*}$ & $\mathrm{D}($ Bank Credit to Construction)-1 & -0.062 \\
D(Remittances)-1 & $+1.169^{*}$ & $\mathrm{D}$ (Remittances)-1 & +0.048 \\
$\mathrm{D}(\mathrm{GDP})-1$ & $-1.792^{*}$ & $\mathrm{D}(\mathrm{GDP})-1$ & $+1.019^{*}$ \\
$\mathrm{C}$ & $+0.157^{*}$ & $\mathrm{C}$ & -0.005 \\
\hline
\end{tabular}

Finally, for the three long term stable relationships, we test their residuals for serial correlation and stability. The results, shown in Table 13-15, reveal that the models do not have serial correlation issues. In addition, Figures 4-6 show that all three models are dynamically stable.

Table 13

Breusch-Godfrey Serial Correlation LM Test

\begin{tabular}{lccc}
\hline \multicolumn{5}{c}{ Total Credit, Remittances \& GDP } \\
\hline F-statistic & 1.955 & Prob. F(1,20) & 0.177 \\
Obs*R-squared & 2.315 & Prob. Chi-Square(1) & 0.128 \\
\hline
\end{tabular}

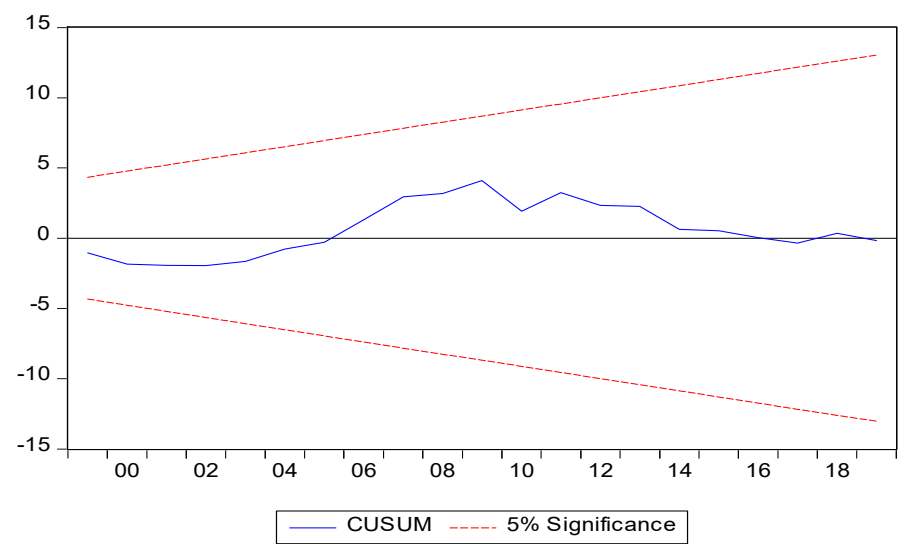

Fig. 4. CUSUM Test: Total Credit, Remittances \& GDP 
Table 14

Breusch-Godfrey Serial Correlation LM Test

\begin{tabular}{llll}
\hline \multicolumn{4}{c}{ Bank Credit to Construction \& Remittances \& GDP } \\
\hline F-statistic & 0.144087 & Prob. F(1,20) & 0.8670 \\
Obs*R-squared & 0.471235 & Prob. Chi-Square(1) & 0.7901 \\
\hline
\end{tabular}

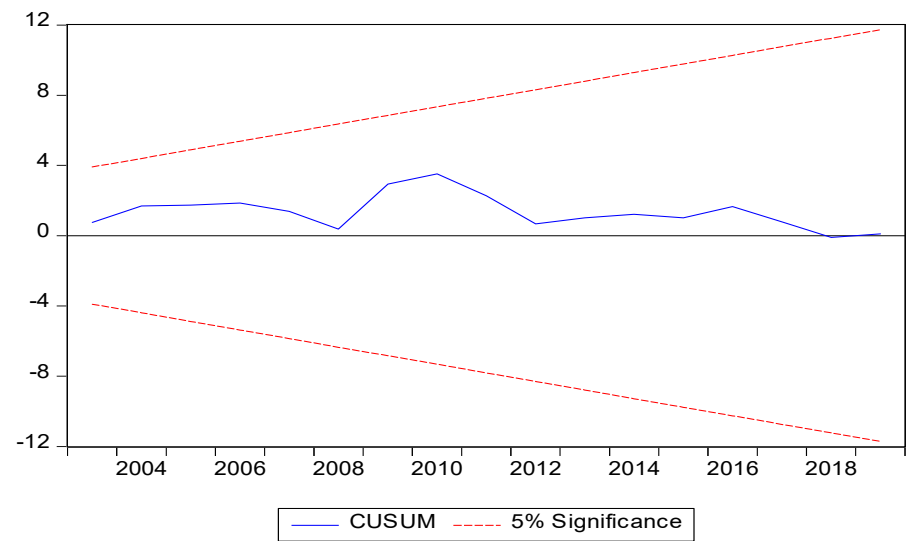

Fig. 5. CUSUM Test: Bank Credit to Construction \& Remittances \& GDP

Table 15

Breusch-Godfrey Serial Correlation LM Test

\begin{tabular}{llcl}
\hline & \multicolumn{4}{c}{ Credit to Individuals \& Remittances \& GDP } \\
\hline F-statistic & 0.330 & Prob. F(1,20) & 0.572 \\
Obs*R-squared & 0.422 & Prob. Chi-Square(1) & 0.515 \\
\hline
\end{tabular}

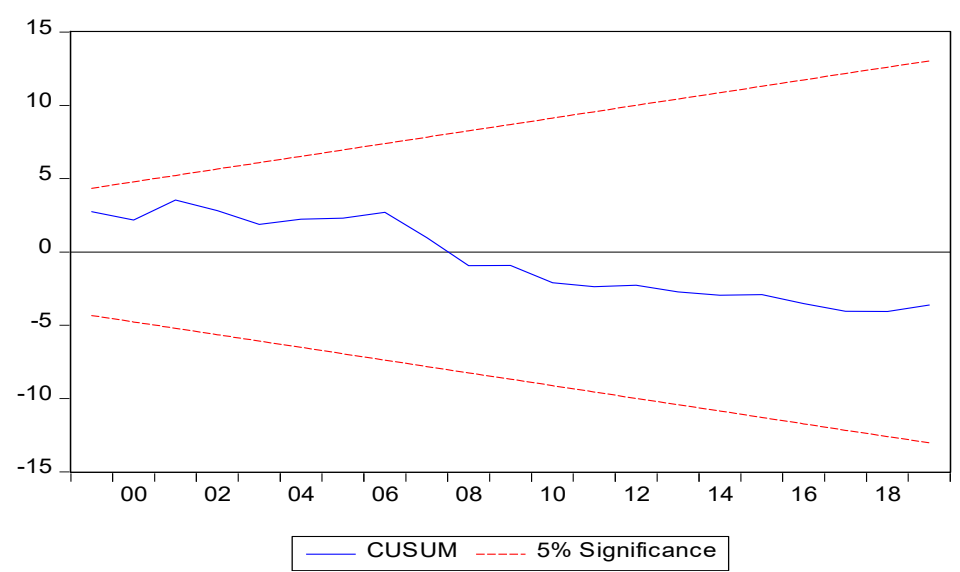

Fig. 6. CUSUM Test: Bank Credit to Individuals \& Remittances \& GDP

\section{A Summary and Conclusions}

As outlined in the introduction, banks provide economies with a myriad of services, and if managed well, they can promote growth and development. This is why, among others, the literature examines the determinants of financial development (measured by, for example, bank credit to the private sector to GDP ratio).

Within the context of the subject matter of the economic importance of bank credit, remittances have been looked at as a possible determinant factor of financial development. However, this literature involves two opposite views on this impact. While some argue that the impact of remittances on bank credit is positive, others argue that the impact is negative.

This paper has looked at the impact of remittances on financial development in the Jordanian scene. The time period 19922019, and some relevant time series techniques are used to examine this relationship. Based on the estimated results, two interesting findings are revealed. First, the impact of remittances on total bank credit is negative. This is also the case on credit to trade. Second, the impact of remittances on credit to individuals and to the construction sector are positive in both cases. This finding reveals that remittances are used for consumption and residential purposes, and hence, increase bank borrowing. 
Based on this macro-level analysis of the impact of remittances on financial development, it would be really interesting, for future research, to develop a survey questionnaire to examine not only the demographics of Jordanians who work abroad (mainly in the Arab Gulf countries), but also what they use their remitted funds for.

\section{References}

Aggarwal, R., Demirgüç-Kunt, A., \& Pería, M. S. M. (2011). Do remittances promote financial development?. Journal of Development Economics, 96(2), 255-264.

Azizi, S. (2020). Impacts of remittances on financial development. Journal of Economic Studies, 47, 467-477.

Bhattacharya, M., Inekwe, J., \& Paramati, S. R. (2018). Remittances and financial development: empirical evidence from heterogeneous panel of countries. Applied Economics, 50(38), 4099-4112.

Brown, R. (1994). Migrants' remittances, savings, and investment in the South Pacific. International Labour Review, 3, 347367.

Calero, C., Bedi, A. S., \& Sparrow, R. (2009). Remittances, liquidity constraints and human capital investments in Ecuador. World Development, 37(6), 1143-1154.

Chowdhury, M.B. (2011). Remittances flow and financial development in Bangladesh. Economic Modelling, 28(6), 600-2608

Cole, S., Sampson, T., \& Zia, B. (2011). Prices or knowledge? What drives demand for financial services in emerging markets?. The Journal of Finance, 66(6), 1933-1967.

Coulibaly, D. (2015). Remittances and financial development in Sub-Saharan African countries, a system approach. Economic Modelling, 45, 249-258.

Demirgüç-Kunt, A., Córdova, E. L., Pería, M. S. M., \& Woodruff, C. (2011). Remittances and banking sector breadth and depth: Evidence from Mexico. Journal of Development Economics, 95(2), 229-241..

Fromentin, V. (2018). Remittances and financial development in Latin America and the Caribbean countries: A dynamic approach. Review of Development Economics, 22(2), 808-826.

Gubert, F. (2002). Do migrants insure those who stay behind? Evidence from the Kayes area (Western Mali). Oxford Development Studies, 30(3), 267-287.

Gupta, S., Pattillo, C. A., \& Wagh, S. (2009). Effect of remittances on poverty and financial development in Sub-Saharan Africa. World development, 37(1), 104-115.

Giuliano, P., \& Ruiz-Arranz, M. (2009). Remittances, financial development, and growth. Journal of Development Economics, 90(1), 144-152.

Kakhkharov, J., \& Rohde, N. (2020). Remittances and financial development in transition economies. Empirical Economics, 59(2), 731-763.

Keho, Y. (2020). Impact of Remittances on Financial Development, Revisiting the Evidence for ECOWAS Countries. Theoretical Economics Letters, 10(1), 169-179.

King, R., \& Levine, R. (1993). Finance, entrepreneurship and growth. Journal of Monetary Economics, 32(3), $513-542$.

Levine, R., Loayza, N., \& Beck, T. (2000). Financial intermediation and growth: Causality and causes. Journal of monetary Economics, 46(1), 31-77.

Lay, S. (2020). Bank credit and economic growth, Short-run evidence from a dynamic threshold panel model. Economics Letters, 192, 14-27.

Lusardi, A., \& Mitchell, O. (2014). The economic importance of financial literacy, Theory and evidence. Journal of Economic Literature, 52, 5-44.

Matei, I. (2020). Is financial development good for economic growth? Empirical insights from emerging European countries. Quantitative Finance and Economics, 4(4), 653-678.

Mehta, A., Mehtal, M., Qamruzzaman, M., \& Serfraz, A. (2021). The role of remittances in financial development, Evidence from nonlinear ARDL and asymmetric causality. Journal of Asian Finance, Economics and Business, 8(3), $139-154$.

McKinnon, R. I. (1973). Money and capital in economic development. Brookings Institution Press, Washington, DC.

Misati, R., \& Kamau, A. (2018). Do migrant remittances matter for financial development In Kenya? Kenya Bankers Association, Working Paper No. 30.

Opoku, E. E. O., Ibrahim, M., \& Sare, Y. A. (2019). The causal relationship between financial development and economic growth in Africa. International Review of Applied Economics, 33(6), 789-812.

Rajan, R. G., \& Zingales, L. (1998). Which capitalism? Lessons form the east Asian crisis. Journal of Applied Corporate Finance, 11(3), 40-48.

Woodruff, C., \& Zenteno, R. (2007). Migration networks and microenterprises in Mexico. Journal of Development Economics, 82(2), 509-528.

Yang, D., \& Choi, H. (2007). Are remittances insurance? Evidence from rainfall shocks in the Philippines. The World Bank Economic Review, 21(2), 219-248. 
(C) 2021 by the authors; licensee Growing Science, Canada. This is an open access article distributed under the terms and conditions of the Creative Commons Attribution (CC-BY) license (http://creativecommons.org/licenses/by/4.0/). 